\title{
KELIMPAHAN DAN KEANEKARAGAMAN KUPU-KUPU DI KECAMATAN TUGUMULYO KABUPATEN MUSI RAWAS
}

\author{
Septiana $^{1 *}$, Tiara Yulisah ${ }^{2}$, dan Dian Samitra ${ }^{3}$ \\ ${ }^{1,2,3}$ Program Studi Pendidikan Biologi STKIP-PGRI Lubulinggau, Lubuklinggau \\ *Coressponding author: septianaimut96@gmail.com
}

\begin{abstract}
This study aims to determine the abundance and diversity of butterflies in Tugumulyo District, Musi Rawas Regency. The study uses exploratory survey methods. Sampling is carried out from 8:00 to 10:00 and 14:00 to 17:00. Butterflies are captured using insect nets. Butterflies obtained are preserved dry to be identified and made into an insectarium. Identification of insects based on the key to determination. Research data includes butterfly species, the number of each species. Data is processed to determine the value of relative abundance, diversity index, dominance and evenness. The results showed that in Tugumulyo Subdistrict there were 49 species, belonging to 5 families: Papilionidae, Nymphalidae, Lycaenidae, Hesperidae and Pieridae. The butterfly species which has the highest abundance is Hympolimnas bolina Linnaeus (Nymphalidae), with a relative abundance of $9.79 \%$. Butterfly ecology index in Tugumulyo District: diversity index 3.19, dominance 0.82 and evenness 1.0 .
\end{abstract}

Keywords: Abundance, Diversity, Butterflies

\section{PENDAHULUAN}

Serangga merupakan sekelompok hewan yang banyak ditemukan, hampir 80 persen dari seluruh hewan yang ada di muka bumi, dengan memiliki bentuk tubuh yang bermacam-macam. Ciri khas dari kelompok ini adalah tubuhnya bersegmensegmen, sehingga dimasukkan ke dalam filum Arthropoda (Saktyowati, 2011). Setidaknya, di dunia tercatat sekitar 750.000 jenis serangga, sedangkan di Indonesia 250.000 jenis (Meilin et al., 2016). Kupu-kupu merupakan jenis serangga termasuk ke dalam Ordo Lepidoptera, aktif pada siang hari (diurnal). Jumlah spesies kupu-kupu yang ditemukan di Indonesia sekitar 2.500 spesies (Nurhakim, 2014).
Kupu-kupu mempunyai peranan yang penting di dunia ini. Serangga tersebut berperan sebagai hewan penyerbuk bunga (pollinator) banyak tumbuhan, sehingga tumbuhan tersebut menghasilkan buah. Peranan ini penting dalam menjaga keseimbangan dalam ekosistem (Fitriani, 2008). Selain itu, kupu-kupu juga dapat dijadikan sebagai bioindikator terhadap perubahan kualitas lingkungan, karena kupu-kupu sangat sensitif terhadap kualitas udara yang buruk dan pencahayaan matahari yang kurang (Noor dan Zen, 2015).

Kelimpahan kupu-kupu di suatu tempat tergantung pada habitat yang banyak terdapat tanaman atau tumbuhan inang sebagai sumber makanan dan tempat perlindungan diri atau berkembang biak. 
Jika kondisi habitat mendukung, maka kupu-kupu dapat melangsungkan hidupnya dari generasi ke generasi (Herlina, 2017).

Keanekaragaman kupu-kupu akan mengalami pengurangan jumlah bahkan mengalami kepunahan lokal hal ini disebabkan oleh adanya perubahan dan penyusutan ekosistem dari banyaknya kegiatan eksploitasi yang sangat cepat, sehingga banyaknya alih fungsi hutan. Luas hutan semakin berkurang dengan bertambahnya jumlah manusia sehingga lahan hutan beralih menjadi lahan pemukiman dan pertanian (Noor dan Zen, 2015). Pengurangan kupu-kupu juga dipengaruhi oleh gangguan lingkungan seperti banyaknya kegiatan transportasi, industri, maupun domestik (Azahra et al., 2016).

Keberagaman jenis kupu-kupu di Pulau Sumatera terus mengalami penurunan. Hal ini disebabkan banyaknya ahli fungsi hutan, sehingga mempengaruhi ketersediaan sumber makanan maupun habitat bagi kupu-kupu (Bibas et al., 2016). Menurut Rahayu et al. (2012) di Pulau Sumatera terdapat sekitar 1.000 jenis kupu-kupu, yang tersebar diseluruh pulau itu, walaupun data mengenai data kelimpahan kupu-kupu di pulau Sumatera belum lengkap. Putri dan Mutiara (2014) melaporkan ada 3 spesies kupu-kupu dari famili Papilionidae, Nymphalidae dan Pieridaedi Kecamatan Sukarami Provinsi
Sumatera Selatan. Maryanti (2017) melaporkan terdapat 35 jenis spesies kupu-kupu dari famili Papilionidae, Pieridae dan Nymphalidae di daerah kawasan wisata Lubuklinggau (Watervang, Bukit Sulap dan Air Terjun Temam)

Kecamatan Tugumulyo merupakan daerah agraris. Wilayah kecamatan ini memiliki luas lahan sekitar $6.770,91$ hektar, terdiri dari 17 desa dan 1 kelurahan. (Kecamatan Tugumulyo, 2016). Berbagai serangga hidup di kawasan itu, karena didukung oleh habitat hidupnya yang terdiri dari berbagai jenis tumbuhan yang ada di daerah itu. Berdasarkan pengamatan, banyak jenis kupu-kupu beterbangan mencari makanannya dan pasangan hidupnya di wilayah itu. Penelitian ini bertujuan untuk mengetahui jenis kupu-kupu yang hidup di daerah Kecamatan Tugumulyo, kelimpahan dan keanekaragamannya.

\section{METODE PENELITIAN}

Penelitian dilakukan pada 17 desa dan1 kelurahan yang ada di Kecamatan Tugumulyo Kabupaten Musi Rawas. Metode yang digunakan adalah metode survei eksploratif (menjelajah). Pengambilan sampel dilakukan pada setiap dusun di masing-masing desa/kelurahan di wilayah Kecamatan Tugumulyo, pada bulan Juni sampai dengan Juli 2018. 
Septiana, dkk: Kelimpahan dan Keanekaragaman Kupu-Kupu di Kecamatan Tugumulyo Kabupaten Musi Rawas

Kegiatan penangkapan kupu-kupu dilakukan pada pagi hari jam 08.00-10.00 dan siang hari jam 14.00-17.00 waktu setempat, menggunakan jaring serangga. Kupu-kupu yang tertangkap dimasukkan ke dalam toples dan diawetkan secara kering untuk tujuan dterminasi dan pembuatan insektarium. Determinasi dilakukan dengan menggunakan kunci determinasi sebagai berikut.

1. Peggei (2006) : Kupu-kupu dilindungi

2. Peggei (2011) : Kupu-kupu Kebun Raya Bogor

- Kelimpahan Relatif (KR)

$$
\mathrm{KR}=\frac{\text { Jumlah individu suatu jenis }}{\text { Jumlah individu seluruh jenis }} \times 100 \%
$$

- Indeks Keanekaragaman Shannon Wiener $\left(\mathrm{H}^{\prime}\right): \mathrm{H}^{\prime}=-\sum \frac{n i}{N} \times \ln \frac{n \mathrm{i}}{N}$

\begin{tabular}{cll}
\hline Indeks Ekologi & \multicolumn{1}{c}{ Nilai } & \multicolumn{1}{c}{ Kategori } \\
\hline Indeks Keanekaragaman (H') & $\mathrm{H}^{\prime} \leq 2,0$ & Rendah \\
& $2,0<\mathrm{H}^{\prime}<3,0$ & Sedang \\
& $\mathrm{H}^{\prime} \geq 3,0$ & Tinggi \\
\hline
\end{tabular}

- Indek Dominansi (C): $C=\Sigma(n i / N)^{2}$

\begin{tabular}{cll}
\hline \multicolumn{1}{c}{ Indeks Ekologi } & \multicolumn{1}{c}{ Nilai } & Kategori \\
\hline Dominansi (C) & $0.00<\mathrm{C}<0,5$ & Rendah \\
& $0,50>\mathrm{C} \leq 0,75$ & Sedang \\
& $0,75>\mathrm{C} \leq 1$ & Tinggi \\
\hline
\end{tabular}

- $\operatorname{Indek} \operatorname{Kemeratan}(\mathrm{E}): \quad \mathrm{E}=\frac{H^{v}}{\operatorname{In.S}}$

\begin{tabular}{llll}
\hline \multicolumn{2}{c}{ Indeks Ekologi } & \multicolumn{1}{c}{ Nilai } & \multicolumn{1}{c}{ Kategori } \\
\hline Indeks & Kemerataan & $\mathrm{E}<0,5$ & Keseragaman populasi kecil, komunitas tertekan \\
(E) & $0,50>\mathrm{E} \leq 0,75$ & Keseragaman populasi sedang, komunitas labil \\
& & $0,75>\mathrm{E} \leq 1$ & Keseragaman populasi tinggi, komunitas stabil \\
\hline
\end{tabular}

\section{HASIL DAN PEMBAHASAN}

Berdasarkan hasil penelitian, terdapat 49 spesies kupu-kupu yang tergolong ke dalam 5 famili, yaitu
Papilionidae, Nymphalidae, Pieridae, Lycaenidae dan Hesperidae. Jenis kupukupu yang termasuk ke dalam masingmasing famili disajikan pada Tabel 1 . 
Tabel 1. Jenis kupu-kupu yang ditemukan di wilayah Kecamatan Tugumulyo, tahun 2018

\begin{tabular}{|c|c|c|c|}
\hline No & Famili & Spesies & Jumlah individu \\
\hline 1 & Pieridae & Appias olferna & 592 \\
\hline 2 & Pieridae & Captopsilia scylla & 84 \\
\hline 3 & Pieridae & Catpsilia pomona & 99 \\
\hline 4 & Pieridae & Ideopsis vulgaris & 12 \\
\hline 5 & Pieridae & Eurema blanda & 339 \\
\hline 6 & Pieridae & Eurema sari & 19 \\
\hline 7 & Pieridae & Leptosia nina & 403 \\
\hline 8 & Pieridae & Parantica aspiasa & 3 \\
\hline 9 & Nymphalidae & Danaus genutia & 31 \\
\hline 10 & Nymphalidae & Ariedne ariadne & 8 \\
\hline 11 & Nymphalidae & Cethosia penthesilea & 12 \\
\hline 12 & Nymphalidae & Doleschallia bisaltide & 306 \\
\hline 13 & Nymphalidae & Elymnias hypermnestra & 93 \\
\hline 14 & Nymphalidae & Euploea mulciber & 59 \\
\hline 15 & Nymphalidae & Hypolimnas bolina & 600 \\
\hline 16 & Nymphalidae & Ideopsis juventra & 26 \\
\hline 17 & Nymphalidae & Junonia almana & 170 \\
\hline 18 & Nymphalidae & Junonia atlites & 511 \\
\hline 19 & Nymphalidae & Junonia hedonia & 24 \\
\hline 20 & Nymphalidae & Junonia orithya & 578 \\
\hline 21 & Nymphalidae & Lexias pardalis & 19 \\
\hline 22 & Nymphalidae & Catopsilia pyranthe & 108 \\
\hline 23 & Nymphalidae & Melanitis leda & 61 \\
\hline 24 & Nymphalidae & Mycalesis perseus & 57 \\
\hline 25 & Nymphalidae & Neptis hylas & 301 \\
\hline 26 & Nymphalidae & Symbrenthias lilaea & 14 \\
\hline 27 & Nymphalidae & Tanaecia palguna & 4 \\
\hline 28 & Nymphalidae & Tanaecia godartii asoka & 7 \\
\hline 29 & Nymphalidae & Cupha erymanthis & 6 \\
\hline 30 & Nymphalidae & Acraea terpsicore & 45 \\
\hline 31 & Papilionidae & Papilio memnon & 122 \\
\hline 32 & Papilionidae & Papilio agamemnon & 233 \\
\hline 33 & Papilionidae & Graphium doson & 260 \\
\hline 34 & Papilionidae & Papilio aristolochae & 17 \\
\hline 35 & Papilionidae & Papilio demoleus & 237 \\
\hline 36 & Papilionidae & Papilio nephelus & 38 \\
\hline 37 & Papilionidae & Papilio polytes & 77 \\
\hline 38 & Hesperidae & Pelopidas agna & 42 \\
\hline 39 & Hesperidae & Erionota thrax & 90 \\
\hline 40 & Hesperidae & Taractrocera archias & 12 \\
\hline 41 & Hesperidae & Udaspes folus & 105 \\
\hline 42 & Lycaenidae & Lampides boeticus & 11 \\
\hline 43 & Lycaenidae & Zizina otis & 161 \\
\hline 44 & Nymphalidae & Flos annilla & 22 \\
\hline 45 & Pieridae & Delias hyparete & 17 \\
\hline 46 & Nymphalidae & Athyma nefte & 8 \\
\hline 47 & Nymphalidae & Cethosia hypsea & 18 \\
\hline 48 & Nymphalidae & Danaus chrysippus & 46 \\
\hline \multirow[t]{2}{*}{49} & Nymphalidae & Danaus hypsea & 23 \\
\hline & & Jumlah & 6130 \\
\hline
\end{tabular}




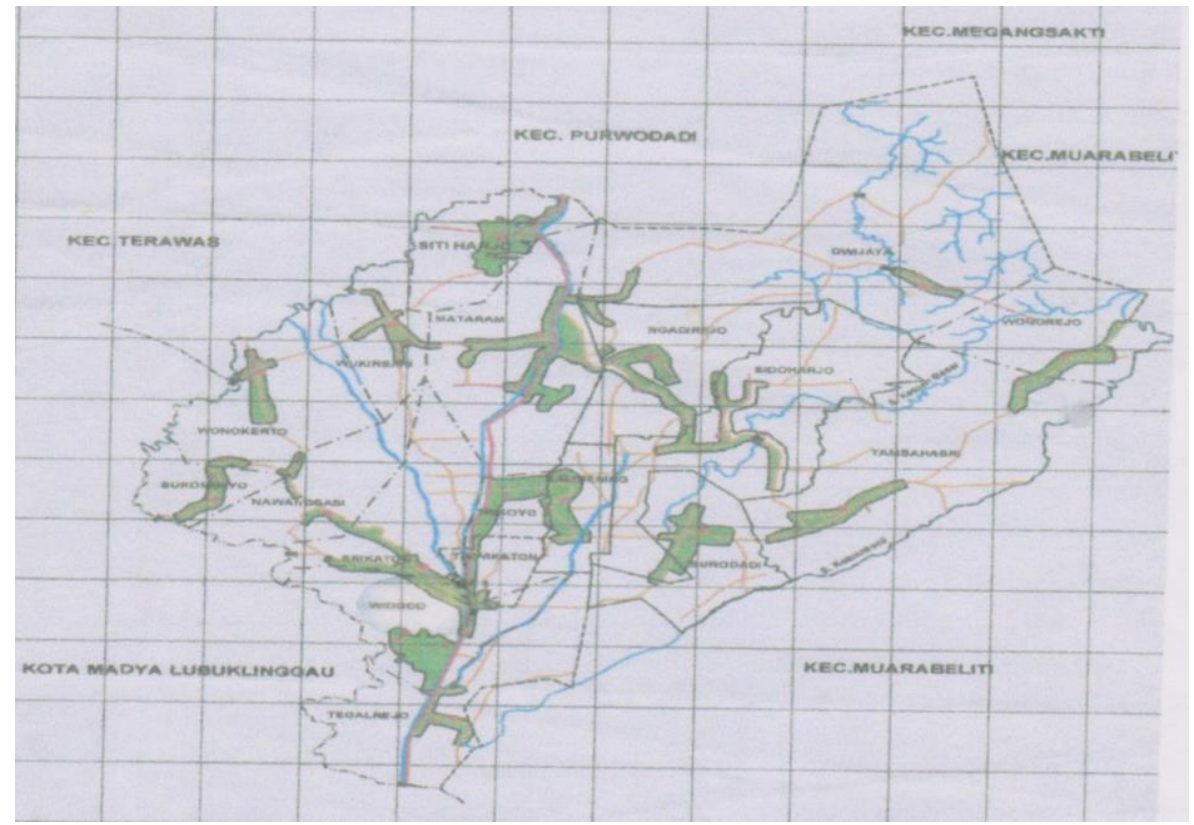

Gambar 1. Peta penyebaran spesies kupu-kupu di wilayah Kecamatan Tugumulyo

Kupu-kupu tersebut menyebar pada wilayah Kecamatan Tugumulyo. Namun pola penyebaran spesies tersebut tidak merata. Ini tergantung kepada jenis tumbuhan sebagai habitat dan sumber makanannya. Kondisi ini dapat disajikan pada peta penyebaran (Gambar 1)

Berdasarkan peta penyebaran spesies kupu-kupu di wilayah Kecamatan Tugumulyo, sebagian besar tanahnya dapat dijadikan sebagai lahan persawahan. Hal ini dikarenakan tanah di Kecamatan Tugumulyo memiliki jenis tanah aluvial sehingga beberapa desa cocok untuk ditanami oleh padi dan berbagai jenis palawija, selain jenis tanah Kecamatan Tugumulyo juga didukung dengan adanyaaliran sungai yang melintasi beberapa desa yang ada di Kecamatan Tugumulyo yang sudah teririgasi secara modern (Sumber: Kecamatan Tugumulyo dalam Angka 2013). Menurut Peggei (2014), penyebaran kupu-kupu memiliki keterkaitan sangat erat dengan tumbuhan pakan ulat, karena kupu-kupu betina akan memilih satu atau beberapa jenis tanaman yang memiliki kerabat dekat. Selain jenis tanaman pakan, yang mempengaruhi keanekaragaman kupu-kupu yaitu tanaman yang mengandung nektar (sari bunga). Jika pembukaan lahan secara terus-menerus menjadi pemukiman warga, dapat mengakibatkan terganggunya kelangsungan hidup kupu-kupu bahkan mengalami kepunahan lokal. Kecamatan Tugumulyo yang terdiri dari 17 desa dan 1 kelurahan, sebagian wilayah Kecamatan Tugumulyo telah mengalami kemajuan hal ini terdapat banyaknya pemungkiman warga dan kendaraan yang melintasi kawasan tersebut, dapat dilihat pada Tabel 2 Kupu-kupu dan Tumbuhan Inang. 
Tabel 2. Kupu-kupu dan Tumbuhan Inang

\begin{tabular}{|c|c|c|c|}
\hline No & Spesies Kupu-kupu & Famili & Tumbuhan inang \\
\hline 1 & Appias olferna & Pieridae & $\begin{array}{l}\text { Semak belukar, rumput cabe, dan dapat ditemukan } \\
\text { terbang didekat aliran air }\end{array}$ \\
\hline 2 & Captopsilia Scylla & Pieridae & Ketepeng \\
\hline 3 & Catpsilia Pomona & Pieridae & Ketepeng \\
\hline 4 & Delias hyparete & Pieridae & Benalu \\
\hline 5 & Eurema blanda & Pieridae & $\begin{array}{l}\text { Ketepeng dan bunga kaliandra serta kacang- } \\
\text { kacangan }\end{array}$ \\
\hline 6 & Eurema sari & Pieridae & $\begin{array}{l}\text { Ketepeng dan bunga kaliandra serta kacang- } \\
\text { kacangan }\end{array}$ \\
\hline 7 & Leptosia nina & Pieridae & $\begin{array}{l}\text { Ketepeng dan bunga kaliandra serta kacang- } \\
\text { kacangan }\end{array}$ \\
\hline 8 & Parantica aspiasa & Pieridae & Bunga vena \\
\hline 9 & Danaus genutia & Nymphalidae & Tanaman widuri \\
\hline 10 & Ariedne Ariadne & Nymphalidae & Jarak dan semak \\
\hline 11 & Cethosia penthesilea & Nymphalidae & Tanaman palem \\
\hline 12 & Doleschallia bisaltide & Nymphalidae & $\begin{array}{l}\text { Ekor pecut kuda, bunga vena, dan sering hinggap } \\
\text { diatas daun pisang }\end{array}$ \\
\hline 13 & Elymnias hypermnestra & Nymphalidae & Tanaman palem \\
\hline 14 & Euploea mulciber & Nymphalidae & Bunga oleander \\
\hline 15 & Hypolimnas bolina & Nymphalidae & Rumput islael \\
\hline 16 & Ideopsis juventra & Nymphalidae & Tanaman sirih \\
\hline 17 & Junonia almanac & Nymphalidae & Bunga oleander \\
\hline 18 & Junonia atlites & Nymphalidae & Bunga oleander \\
\hline 19 & Junonia hedonia & Nymphalidae & Bunga oleander \\
\hline 20 & Junonia orithya & Nymphalidae & Bunga oleander dan padang rumput \\
\hline 21 & Lexias pardalis & Nymphalidae & Buah geluk \\
\hline 22 & Melanitis leda & Nymphalidae & Alang-alang \\
\hline 23 & Catopsilia pyranthe & Nymphalidae & Kacang panjang \\
\hline 24 & Mycalesis perseus & Nymphalidae & Bunga oleander \\
\hline 25 & Neptis hylas & Nymphalidae & Tanaman padi \\
\hline 26 & Symbrenthias lilaea & Nymphalidae & Bunga oleander \\
\hline 27 & Tanaecia palguna & Nymphalidae & Tanaman rukam \\
\hline 28 & Tanaecia godartii asoka & Nymphalidae & Tanaman rukam \\
\hline 29 & Cupha erymanthis & Nymphalidae & Tanaman rukam \\
\hline 30 & Papilio memnon & Papilionidae & Jeruk, sirsk dan gelodokan tiang \\
\hline 31 & Papilio Agamemnon & Papilionidae & Jeruk, sirsk dan gelodokan tiang \\
\hline 32 & Graphium doson & Papilionidae & Jeruk, sirsk dan gelodokan tiang \\
\hline 33 & Papilio aristolochae & Papilionidae & Jeruk, sirsk dan gelodokan tiang \\
\hline 34 & Papilio demoleus & Papilionidae & Jeruk, sirsk dan gelodokan tiang \\
\hline 35 & Papilio meтnоo & Papilionidae & Jeruk, sirsk dan gelodokan tiang \\
\hline 36 & Papilio nephelus & Papilionidae & Jeruk, sirsk dan gelodokan tiang \\
\hline 37 & Papilio polytes & Papilionidae & Jeruk, sirsk dan gelodokan tiang \\
\hline 38 & Pelopidas agna & Hesperiidae & Bunga olender \\
\hline 39 & Erionota thrax & Hesperiidae & Tanaman pisang \\
\hline 40 & Taractrocera archias & Hesperiidae & Bunga olender dan padi \\
\hline 41 & Udaspes folus & Hesperiidae & Kunyit dan jahe \\
\hline 42 & Lampides boeticus & Lycaenidae & Padang rumput \\
\hline 43 & Zizina Otis & Lycaenidae & Padang rumput \\
\hline
\end{tabular}


Septiana, dkk: Kelimpahan dan Keanekaragaman Kupu-Kupu di Kecamatan Tugumulyo Kabupaten Musi Rawas

Tabel 3. Nilai kelimpahan, keragaman, dominansi dan kemerataan spesies kupu-kupu di wilayah Kecamatan Tugumulyo, tahun 2017.

\begin{tabular}{|c|c|c|c|c|c|}
\hline No & Spesies kupu-kupu & $\begin{array}{c}\text { Kelimpahan } \\
\text { (KR) }\end{array}$ & $\begin{array}{c}\text { Keragaman } \\
\left(\mathbf{H}^{\prime}\right)\end{array}$ & $\begin{array}{c}\text { Dominasi } \\
(\mathbf{C})\end{array}$ & $\begin{array}{c}\text { Kemerataan } \\
(\mathbf{E})\end{array}$ \\
\hline 1 & Appias olferna & 9.66 & 0.225737 & 0.096574 & \\
\hline 2 & Captopsilia Scylla & 1.37 & 0.058788 & 0.013703 & 0.821348 \\
\hline 3 & Catpsilia Pomona & 1.62 & 0.066632 & 0.016150 & \\
\hline 4 & Ideopsis vulgaris & 0.20 & 0.012208 & 0.001958 & \\
\hline 5 & Eurema blanda & 5.53 & 0.160096 & 0.055302 & \\
\hline 6 & Eurema sari & 0.31 & 0.017904 & 0.0031 & \\
\hline 7 & Leptosia nina & 6.57 & 0.178951 & 0.065742 & \\
\hline 8 & Parantica aspiasa & 0.05 & 0.00373 & 0.000489 & \\
\hline 9 & Danaus genutia & 0.51 & 0.026737 & 0.005057 & \\
\hline 10 & Ariedne Ariadne & 0.13 & 0.008668 & 0.001305 & \\
\hline 11 & Cethosia penthesilea & 0.20 & 0.012208 & 0.001958 & \\
\hline 12 & Doleschallia bisaltide & 4.99 & 0.149624 & 0.049918 & \\
\hline 13 & Elymnias hypermnestra & 1.52 & 0.063543 & 0.015171 & \\
\hline 14 & Euploea mulciber & 0.96 & 0.044692 & 0.009625 & \\
\hline 15 & Hypolimnas bolina & 9.79 & 0.227473 & 0.097879 & \\
\hline 16 & Ideopsis juventra & 0.42 & 0.02317 & 0.004241 & \\
\hline 17 & Junonia almanac & 2.77 & 0.099425 & 0.027732 & \\
\hline 18 & Junonia atlites & 8.34 & 0.207116 & 0.083361 & \\
\hline 19 & Junonia hedonia & 0.39 & 0.021701 & 0.003915 & \\
\hline 20 & Junonia orithya & 9.43 & 0.222655 & 0.09429 & \\
\hline 21 & Lexias pardalis & 0.31 & 0.017904 & 0.0031 & \\
\hline 22 & Catopsilia pyranthe & 1.76 & 0.071157 & 0.017618 & \\
\hline 23 & Melanitis leda & 1.00 & 0.045875 & 0.009951 & \\
\hline 24 & Mycalesis perseus & 0.93 & 0.043498 & 0.009299 & \\
\hline 25 & Neptis hylas & 4.91 & 0.049103 & -3.01384 & \\
\hline 26 & Symbrenthias lilaea & 0.23 & 0.01389 & 0.002284 & \\
\hline 27 & Tanaecia palguna & 0.07 & 0.004786 & 0.000653 & \\
\hline 28 & Tanaecia godartii asoka & 0.11 & 0.007737 & 0.001142 & \\
\hline 29 & Cupha erymanthis & 0.10 & 0.006782 & 0.000979 & \\
\hline 30 & Acraea terpsicore & 0.73 & 0.036076 & 0.007341 & \\
\hline 31 & Papilio memnon & 1.99 & 0.077955 & 0.019902 & \\
\hline 32 & Papilio Agamemnon & 3.80 & 0.124289 & 0.03801 & \\
\hline 33 & Graphium doson & 4.24 & 0.134041 & 0.042414 & \\
\hline 34 & Papilio aristolochae & 0.28 & 0.016328 & 0.002773 & \\
\hline 35 & Papilio demoleus & 3.87 & 0.125764 & 0.038662 & \\
\hline 36 & Papilio nephelus & 0.62 & 0.031512 & 0.006199 & \\
\hline 37 & Papilio polytes & 1.26 & 0.054982 & 0.012561 & \\
\hline 38 & Pelopidas agna & 0.69 & 0.034143 & 0.006852 & 0.821348 \\
\hline 39 & Erionota thrax & 1.47 & 0.061974 & 0.014682 & \\
\hline 40 & Taractrocera archias & 0.20 & 0.012208 & 0.001958 & \\
\hline 41 & Udaspes folus & 1.71 & 0.069663 & 0.017129 & \\
\hline 42 & Lampides boeticus & 0.18 & 0.011346 & 0.001794 & \\
\hline 43 & Zizina Otis & 2.63 & 0.09559 & 0.026264 & \\
\hline 44 & Flos annilla & 0.36 & 0.020205 & 0.003589 & \\
\hline 45 & Delias hyparete & 0.28 & 0.016328 & 0.002773 & \\
\hline 46 & Athyma nefte & 0.13 & 0.008668 & 0.001305 & \\
\hline 47 & Cethosia hypsea & 0.29 & 0.017121 & 0.002936 & \\
\hline 48 & Danaus chrysippus & 0.75 & 0.036712 & 0.007504 & \\
\hline \multirow[t]{2}{*}{49} & Danaus hypsea & 0.38 & 0.020957 & 0.003752 & \\
\hline & Jumlah & 100 & 3.196537 & 1 & \\
\hline
\end{tabular}


Putri dan Mutiara (2014) menyatakan bahwa banyaknya ahli fungsi hutan menjadi kawasan pemukiman dan industri secara terus menerus akan mengakibatkan terdesaknya habitat dari kupu-kupu. Penelitian dilaksanakan pada saat itu dalam kondisi kemarau di mana pada saat penelitian suhu lingkungan berkisar 30\% dengan kelembaban udara $80 \%$ dan pada saat itu banyak ditemukan tanaman yang sedang berbunga seperti bunga cosmos, zizina dan beragam jenis tumbuhan tingkatrendah lainnya, kupukupu yang sering terlihat yaitu golongan Nymphalidae seperti (Hypolimnas bolina, Junonia orithya dan Junonia atlites). Ketiga spesies ini menyukai pencahayaan matahari yang banyak dan Peridae (Zizina otis) yang memiliki kemampuan terbang rendah. Oleh karena itu, perlu dilakukan pendataan mengenai kelimpahan dan keanekaragaman dari spesies yang ditemukan di Kecamatan Tugumulyo. Berdasarkan hal tersebut diperoleh gambaran mengenai kelimpahan, keragaman, dominansi dan kemerataan spesies kupu-kupu di wilayah Kecamatan Tugumulyo (Tabel 3).

Berdasarkan Tabel 3, bahwa kupukupu dengan kelimpahan tertinggi yaitu pada spesies Hypolimnas bolina dengan kelimpahan relatif $9.74 \%$, Hypolimnas bolina dapat ditemukan banyak terbang didekat tanaman pisang, kebun warga, tanaman cosmos, tanaman zinzia, dan terbang di padang rumput. Hypolimnas bolina merupakan salah satu spesies yang termasuk kedalam famili Nymphalidae yang memiliki persebaran yang tinggi dalam ordo Lepidoptera, selain itu besarnya proporsi famili dari Nymphalidae karena bersifat polyfag yaitu dapat memakan lebih dari satu jenis tanaman inang sehingga bila makanan utama dari famili ini maka kupu-kupu dapat memakan tanaman yang cocok untuk setiap spesies, sehingga memungkinkan Nymphalidae dapat memenuhi kebutuhannya akan tumbuhan inang, jika tumbuhan maupun tanaman inang utamanya tidak tersedia maka kupu-kupu akan melakukan imigrasi ketempat lain (Herlina, 2017). Selain bersifat polyfag, tingginya famili dari Nymphalidae mudah beradaptasi dengan lingkungan dan keberadaan kupu-kupu famili Nymphalidae sangat bergantung pada tumbuhan pakannya, baik sebagai inang bagi larva maupun sebagai sumber nektar bagi imago, dengan lokasi penelitian yang memiliki beragam tanaman inang yang cocok untuk setiap spesies kupu-kupu (Santosa et al., 2017). Famili Nymphalidae dapat dengan mudah ditemukan di sepanjang musim karena bersifat generalis. Selain itu, jenis Nymphalidae tidak tergantug pada 
Septiana, dkk: Kelimpahan dan Keanekaragaman Kupu-Kupu di Kecamatan Tugumulyo Kabupaten Musi Rawas

keberadaan nektar bunga saja tetapi famili ini mampu mendapatkan sumber pakan dari buah yang busuk maupun urin dari hewan yang sudah mati (ikan) (Irni et al., 2010). Selain wilayah Kecamatan Tugumulyo didominasi oleh hewan ternak seperti sapi, kambing dan unggas, sehingga pada saat musim ternak, banyak ditemukan golongan kupu-kupu yang hinggap secara berkelompok.

Indek Keanekaragaman spesies kupu-kupu sebesar 3,19 yang dikategorikan tinggi, famili yang paling dominan dalam penelitian ini yaitu famili Nymphalidae yang ditemukan ada 29 spesies, hal ini dikarenakan famili Nymphalidae jumlah spesies yang relatif banyak. Selain memiliki jumlah spesies jumlah yang paling banyak, tingginya populasi kupu-kupu dari famili Nymphalidae pada lokasi lokasi pengamatan juga karena adanya vegetasi yang sesuai untuk keberlangsungan hidup kupu-kupu tersebut seperti terdapatnya tumbuhan inang dan tanaman pakan kupukupu, baik sebagai sumber makanan maupun sebagai tempat berlindung, famili Nymphalidae yang banyak ditemukan yaitu Hympolimnas bolina yang hampir setiap lokasi penelitian ditemukan (Tatang et al., 2018). Selain itu, tingginya keanekaragaman kupu-kupu karena adanya faktor yang mendukung pertumbuhan kupu-kupu untuk melakukan reproduksi dan berkembang seperti banyak beragam tanaman inang yang disukai oleh kupukupu serta faktor lingkungan seperti suhu dan kelembaban. Hal ini karena kupu-kupu merupakan hewan diurnal yaitu aktif disiang hari sehingga pada saat penelitian hal ini sesuai dengan suhu $30^{\circ} \mathrm{C}$ dengan didukung oleh kelembaban yang tinggi pula sekitar 80\% (Dewi et al., 2016). Setiap spesies kupu-kupu memiliki perbedaan kesukaan terhadap sinar matahari langsung, sehingga pada penelitian yang telah dilaksanakan mendapat famili dari Hesperididae dan Lycanidae yang ditemukan sedikit. Hal ini dikarenakan pada saat penelitian dalam kondisi cerah sehingga famili Hesperididae dan Lycanidae umumnya beraktivitas pada awal pagi hari dan menjelang malam hari, hal ini dikarenakan kupu-kupu jenis ini menghisap cairan yang berasal dari embun. Pada siang hari mereka akan bersembunyi dibawah daun atau tempat-tempat teduh dan terlindungi sehingga sulit dikoleksi.

Dominansi dari spesies kupu-kupu yang ditemukan memiliki nilai 0.82 yang dikategorikan tinggi, kupu-kupu yang memiliki dominansi dari lokasi penelitian yaitu famili Nymphalidae dan kemerataan 1 yang dikategorikan tinggi sehingga Indeks kemerataan spesies yang tinggi 
menunjukkan bahwa tidak ada satu spesies yang mendominasi spesies lainnya. Semakin tinggi nilai kemerataan spesies mengindikasikan bahwa jumlah individu setiap spesies semakin seragam.

\section{KESIMPULAN}

Berdasarkan hasil penelitian, telah ditemukan kupu-kupu sebanyak 49 spesies, yang tergolong kedalam Papilionidae, Nymphalidae, Lycaenidae,
Hesperidae dan Pieridae. Jenis kupu-kupu yang mempunyai kelimpahan tertinggi yaitu Hympolimnas bolina (Nymphalidae) dengan kemerataan relatif sebesar 9,79\% dan indeks keanekaragam 3,19 serta indeks dominansi 0,82. Jumlah spesies paling banyak adalah famili Nymphalidae sebanyak 29 spesies.

\section{DAFTAR PUSTAKA}

Azahra SD, Sasyud B, dan Fanthah N. 2016. Perbandingan komunitas kupu-kupu pada berbagai tipe, karakteristik dan gangguan lingkungan Hutan Kota. Media Konservasi, 21 (2) :9.

Bibas E, Ahmad M, dan Desita S. 2016. Keanekaragaman kupu-kupu di kawasan Gunong Bonsu Kabupaten Rokan Hulu, Provinsi Riau. Jurnal Riau Biologia, 1(6): 39.

Dewi B, Hamidah A, dan Siburian J. 2016. Keanekaragamn dan kelimpahan jenis kupu-kupu (Lepidoptera; Rhopalocera) di sekitar Kampus Pinang Masak Universitas Jambi. Biospecies, 9 (2): 34.

Fitriani L. 2008. Mengenal dunia kupukири. Jakarta Timur: Sahala Adidayatama.

Herlina H. 2017. Kelimpahan kupu-kupu Nymphalidae di kawasan air terjun Parangloe Kabupaten Gowa. Skripsi. Jurusan Biologi pada Fakultas Sains dan Teknologi UIN Alauddin Makassar. Online at http://repositori.uin-alauddin.ac.id.
Irni J, Masy'ud B, dan Haneda NF. 2017. Keanekaragaman jenis kupu-kupu berdasarkan tipe tutupan lahan dan waktu aktifnya di kawasan penyangga Tangkahan Taman Nasional Gunung Leuser. Media Konservasi, 21 (3): 226.

Jumar J. 2000. Entomologi Pertanian. Jakarta: PT Rineka Cipta.

Kecamatan Tugumulyo. 2016. Rencana Strategis Kecamatan Tugumulyo Tahun 2016-2021. Pemerintah Kabupaten Musi Rawas.

Lamatoa DC, Koneri R, Siahaan R dan Maabuat P. 2013. Populasi kupukupu (Lepidoptera) di Pulau Mantehage Sulawesi Utara. Jurnal Ilmiah Sains, 13 (1): 52.

Maryanti D. 2017. Inventarisasi jenis kupu-kupu (Lepidoptera) di kawasan tempat wisata Kota Lubuklinggau diimplementasikan sebagai booklet. Skripsi. MIPA Biologi STKIP-PGRI Lubuklinggau. Online at https://www.e-library.stkippgrilubuklinggau.ac.id.

Meilin A dan Nasamsir. 2016. Serangga dan peranannya dalam bidang 
pertanian dan kehidupan. Jurnal Media Pertanian, 1 (1): 18-28.

Noor R dan Zen S. 2015. Studi keanekaragaman kupu-kupu di bantaran Sungai Batang Hari Kota Metro sebagai sumber belajar Biologi materi keanekaragamam. Bioedukasi, 6 (5):72-73.

Peggie D dan Amir M. 2006. Practical guide to the butterflies of Bogor Botanic Garden. Jakarta: Pandu Aksara Publishing.

Peggie D. 2011. Panduan Praktis KupuKupu Di Kebun Raya Bogor. Bogor: Puslitbang Biologi LIPI.

Putri E dan Mutiata D. 2014. Keanekaragaman kupu-kupu di Kecamatan Sukarame Kota Palembang Provinsi Sumatera Selatan. Sainmatika, 11 (2): 35.

Rahayu SE dan Basukriadi A. 2012. Kelimpahan dan keanekaragaman spesies kupu-kupu (Lepidoptera, Rhopalocera) pada berbagai tipe habitat Muhammmad Sabki Kota Jambi. Biospesies, 5 (2):1.

Saktyowati DO. 2011. Pengelompokan Makhluk Hidup. Jakarta Timur: CV Rama Edukasitama.

Santosa Y, Purnamasari I, dan Wahyuni I. 2017.

Perbandingan keanekaragaman kupu-kupu antara tipe tutupan lahan hutan dengan kebun sawit. Pros Sem Nas Masy Biodiv Indon. 3(1):106.

Soekardi H, Larasati A, Djausal A, dan Martinus. 2016. Backyard conservation taman Кири-kuри di halaman rumah. Bandar Lampung: Yayasan Sahabat Alam.

Soekardi H, Larasati A, Djausal A, dan Martinus. 2016. Кири-kири Lampung Taman Kupu-kupu Gita Persada. Bandar Lampung: Yayasan Sahabat Alam.

Suwarno S, Fuadi S, dan Mahmud AH. 2013. Keragaman dan kelimpahan kupu-kupu pasca tsunami di kawasan Sungai Sarah, Aceh Besar. Prosiding Semirata FMIPA Universitas Lampung. Jurusan Biologi FMIPA Universitas Syiah Kuala.

Tatang, V., C., L., Melanie, E., Kasmara, H., dan Wawan. 2018. Keanekaragaman Jenis Kupu-kupu Famili Nymphalidae dan Pieridae di kawasan Cirengganis dan Padang Rumput Cikamal Cagar Alam Penanjung Pangandaran. Jurnal Agrikultura, $\quad$ 29(1):3. 